\title{
Pasienten er fasiten!
}

Alle pasienter er forskjellige og trenger spesiell tilnærming fra legens side for å føle seg $\mathrm{i}$ ivaretatt (1). Dette innebærer at legen i stor grad må kunne variere sin måte å kommunisere på. Likevel prøver vi i utdanningen av leger å lære bort visse «tommelfingerregler» for god kommunikasjon. I en del av reglene fremgår det klart hva man ikke skal gjøre. Den beskrevne konsultasjonen illustrerer godt hvordan det går om man helt neglisjerer en del av disse prinsippene, og er derfor en nyttig påminnelse for noen og hver av oss.

\section{Tre kardinalfeil}

«Hvorfor ligger du her?» innleder legen med, og dermed er allerede tilliten svekket. Pasienter vil lett oppfatte dette spørsmålet enten som kritikk (du skulle ikke vært her!) eller som at legen er helt desorientert (vet ikke legen at jeg er syk og skal undersøkes?). Vi lærer studentene at de i stedet skal begynne med setninger som: Hva kan jeg hjelpe deg med i dag? Hva har brakt deg hit i dag? Hva er problemet her? osv. I starten gjelder det å etablere øyekontakt og skape allianse. Turnuslegen valgte i stedet å interessere seg for en bok som pasienten hadde, satte seg med ryggen til og eksaminerte på et uforståelig medisinsk fagspråk mens han skrev på PC.

Det andre problemet som illustreres, er spørsmålet om hvor mye av sin diagnostiske usikkerhet legen skal dele med pasienten. Pasienter med somatiske lidelser vil også ofte ha nervøse reaksjoner (2). Tommelfingerregelen er at man bør være tilbakeholden med dette, men også se an pasienten. Hvordan tar pasienten det om man begynner å reflektere høyt over mulige diagnoser? Blir pasienten usikker og redd? Denne pasienten ble forståelig nok redd over å få høre de verst mulige scenarier. Da pasienten meldte fra om det, gjentok og overdrev legen det i enda høyere grad i stedet for å ta signalet. Pasienten og kontaktforholdet er fasiten på om kommunikasjonen går i god retning. Hvis kontakten blir dårligere, ikke gjør mer av det samme!

Det tredje problemet som illustreres er viktig. Hvordan skal vi som leger håndtere kritikk og misnøye fra pasientene? Enkelte leger vil nok dessverre prøve å overhøre det og late som ikke noe. Risikoen for at de da selv gjør feil og faktisk blir kritikkverdige, vil øke. Tillit fra pasienten er avgjørende for at legen skal få tak i nødvendige medisinske opplysninger, og for at pasienten etterlever behandlingen. Denne tilliten kan imidlertid fort spoleres. Vi lærer studentene at de alltid må si ifra om det på en rolig måte hvis de oppfatter at pasienten er misfornøyd, kritisk eller sint. Ved å vise at man er villig til å lytte til kritikken, ev. revurdere noe man har gjort eller endre sin stil i konsultasjonen, vil som regel tilliten gjenopprettes - til beste for begge parter. Denne legen gjorde det motsatte: Han kritiserte pasienten for hans misnøye og attribuerte kritikken til pasientens mulige hjertesykdom! I tillegg gikk han til motangrep: Ikke overprøv legen din! Leger er betalt for å tåle kritikk, også om den er usaklig, fra pasienter i nød. Aldri gå til motangrep!

\section{Oppsummering}

Denne konsultasjonen viser at man kan ha kommet gjennom et medisinstudium og blitt turnuslege uten å ha lært seg noen av de viktigste håndgrepene $i$ et godt legepasient-forhold. Denne turnuslegen er dessverre antakelig ikke den eneste som fortsatt har mye å lære $(3,4)$. Også undersøkelser vi har gjort ved vårt institutt viser det. Det er stort behov for at turnuslegene blir fulgt opp med veiledet trening i hovedprinsippene for god klinisk kommunikasjon. Noen ganger er det slik at vi som leger er godt fornøyd med konsultasjonen, mens pasienten ikke er det. Da bør vi reflektere over hvorfor det ble slik. Det er pasienten som er fasiten.

\section{Per Vaglum}

p.j.w.vaglum@medisin.uio.no

Avdeling for atferdsfag

Det medisinske fakultet

Universitetet i Oslo

Postboks 111 Blindern

0317 Oslo

\section{Oppgitte interessekonflikter: Ingen}

\section{Litteratur}

1. Vaglum $P$, Finset A, red. Helse, sykdom og atferd innføring i medisinske atferdsfag. 2. utg. Oslo: Cappelen Akademisk Forlag, 2007.

2. Hem E, Vaglum P. Fyrand L et al, red. Pasienten og sykdommen - psykiske faktorer ved somatisk sykdom. Oslo: Gyldendal Akademisk, 2007

3. Kringlen E, Finset A. Den kliniske samtalen: kommunikasjon og pasientbehandling. 2. utg. Oslo: Gyldendal Akademisk, 2007.

4. Malterud K, red. Legekunst i praksis: kommunikasjon lege-pasient. Oslo: Universitetsforlaget, 2006.

Manuskriptet ble mottatt 17.11. 2008 og godkjent 11.12. 2008. Medisinsk redaktør Erlend Hem. 